\title{
AN UNKNOWN, BUT KEY PLAYER IN THE TELEVISION MARKET
}

\author{
THE TELEVISION RETAILER AND THE CASE \\ OF BLACK AND WHITE TV SETS IN FRANCE \\ ( $1950-1987$ )
}

\author{
Isabelle Gaillard \\ Université Pierre-Mendès-France \\ Sciences Humaines et Sociales \\ BP 47, 38040 Grenoble Cedex \\ France \\ isabelle.gaillard@upmf-grenoble.fr
}

How did you launch the TV set market in France at the beginning of the fifties?

We relied on the retail network!, so said the CEO of the radio-television group of the electrical goods company Thomson, in answer to this question.

What was the role of the retailers in promoting, supporting and developing black and white television from its beginning in 1948 to its end in 1984? Did they play an increasingly important role?

Historians of television broadcasting haven't been very interested in studying television retailers. Yet they were essential - if hidden - building blocks for the development of television. Thanks to the French legislation, retailers have played a key role in the market; above all they were in direct contact with consumers, who were to be viewers. By selling television, they were both promoting the technical object and its content, the TV set and the television programmes. In fact, they played a vital part in the evolution of the black and white TV set during the period.

In France, the TV set was considered as a technical object in the fifties and small 'traditional' retailers were leaders in the market. Mostly coming from the pre-war network of affiliated radio stores, bound by contracts with the manufacturers, the retailers were in a dominant position because they were able to give advice and provide after-sale services. French set makers ensured they had adequate training and this was also a way to sell their companies' brand. This model of the retail store operating for one or several brands, combining efficient sales but especially good technical support, was to dominate the retail market. From the fifties, price discounters and specialist outlets attempted to take a slice out of the television market, but they were essentially restricted to the Paris region till the end of the sixties. By the 1970s, there was a crucial turning point as the TV set was no longer regarded as a technical and rare product but as an everyday mass household item and as a result hypermarkets became market leaders as well as the competition enemies of the manufacturers. At this time, price had begun to matter much more than traditional service and technical after sales. 


\section{Selling a Durable and Technical Good: The Preponderance of "Traditional" Retailers until the Beginning of the Seventies}

In the first phase of expansion, television was for quite a long period of time, a technical novelty and a very expensive product. Closely tied to manufacturers, capable of providing after-sale services, small 'traditional' retailers were key actors in the distribution system till the beginning of the seventies.

\subsection{The "Traditional" Retailer: A Major Player}

In France, during the 1950 s about $85 \%$ of radio and TV sets, were sold by a direct manufacturer-retailer-consumer distribution network. ${ }^{1}$ This direct network still controlled more than $75 \%$ of black and white TV sets retailing at the beginning of the seventies. ${ }^{2}$ According to the top manager of Thomson's radio-television, there were two actors in the distribution channel: those closely tied to the companies and those more loosely tied to them, dealers and sales 'agents's with the latter ones more numerous. ${ }^{4}$ They often sold several brands although discount arrangements actually resulted in more of a focus on one brand than others. ${ }^{5}$ By 1962, the Schneider Radio-Télévision network had grown to 3000 retail stores with $25 \%$ of them concentrated on exclusive rights. ${ }^{6}$

Mostly derived from the pre-war networks of affiliated radio stores, these retailers were actively canvassed. ${ }^{7}$ Electrical goods makers launched regional sales offices, where appointed agents visited the retailers of their region, to cultivate and take orders and pass them on to the manufacturers. Manufacturers were legally bound to a dealer under a concession contract, which was not necessarily exclusive and retailers had to deal with manufacturers' sales' inspectors. ${ }^{8}$ They also had specific sales' quotas ${ }^{9}$ and the manufacturers decided what commercial policy had to be implemented. ${ }^{10}$ They also provided extensive support to their retail networks and in these ways, they exerted control over the distribution of their products.

\subsection{A System that Empowered Manufacturers}

Thanks to the 'traditional' retailer, manufacturers were able to closely monitor their brand image; they were also able to control the prices as well as the tracking of their products. However, according to one contemporary study, 'for all they depended on their supplier, retailers were not very free to negotiate the prices of sets in front of the buyer'11 and prices and margins reflected this. According to the National Federation of Electronic Industries, mark-up rates - which in

\footnotetext{
Fédération Nationale des Industries Electroniques, L'industrie électronique, Société nouvelle Mercure, 1959 , p.87 -88.

2 CETELEM, Votre dossier brun pour 1975, CETELEM's archives, Paris, p. 21

3 Interview with a former managing director of Thomson, 2004.

${ }^{4}$ According to Jean -Louis Loubet, all the agents in the car dealership were directly integrated into the network. They were contractually bound to a car dealer accountable to their agents in front of the car manufacturer. See J.-L. Loubet, Citroën, Peugeot, Renault et les autres... Histoire de stratégies d'entreprises, E.T.A.I., 1999, p.264.

5 J. Fargeaud, 'TV qui te construit?,' Electro-Magazine, March-April 1957, 35

6 'Schneider Radio -Télévision, comment passer à la dimension européenne,' Entreprise, 23 June $1962,22$.

7 'TV qui te construit?,' p. 35.

8 Centre d'étude des revenus et des coûts, Les circuits de distribution des appareils électrodomestiques, La Documentation Française, 1984 , p.36.

9 'Pourquoi et comment a réussi Grandin,' Electro-Magazine, May-June 1957, p. 10.

10 Ibid.

11 F. Dupuy, J.-C. Thoenig, La loi du marché, l'électroménager en France, aux Etats-Unis et au Japon, L'Harmattan, 1986, p.103.
} 
1939 were much higher than $40 \%$ - had been gradually cut down to about $27 \%$ for televisions by the late 1950 s. ${ }^{12}$ This $^{2}$ was to become an illegal system especially within the developing frameworks of the free Common Market. Moreover, since 1945 suppliers were obliged to sell to any buyer who wanted to buy something ${ }^{13}$ and the most important issue for French legislators was a low price. ${ }^{14}$ However, people did not only buy a TV set because it was reasonably priced, they also needed to run their television and to do this, they needed after-sale services.

It was therefore of great importance for the manufacturer 'to find retailers qualified for this job in every important locality. ${ }^{15}$ Special rebates were granted to retailers who were in a position to assure the maintenance and technical servicing of their products. ${ }^{16}$ Manufacturers set up regional offices 'which offer storage and physical distribution of products as well as maintenance' to retail stores..$^{17}$ They also held specialist training courses in their factories for their retailers. ${ }^{18} \mathrm{At}$ the end of the 1950s, a Centre of Studies of Trade for retailers' professional training was specifically created for the radio and television sector. ${ }^{19}$ Some dealers also created their own provincial professional schools. ${ }^{20}$

At the same time, manufacturers valued retailers' shop windows for television displays as these shop windows promoted public awareness of television. In 1951, the Philips' Head of Television Department in France found it very annoying that shop windows were not as productive as they should be. ${ }^{21}$ Indeed, very frequently, the very first contact people had with television was made through retailers shop windows. A television programme on this subject was shown in French daily news programmes in 1950; the programme was dedicated to '[t]elevision's manufacturers' and demonstrators' efforts to support the Tour de France. It was an interesting topic in significant ways, as the public service broadcasters and television manufacturers used sport as a way to sell their television sets: the promotion of the Tour de France was linked to the promotion of television. This illustrates clearly that manufacturers as well as broadcasters, at the beginning of this period, relied on TV shop windows and cafes as the prime vehicles for the popular dissemination of television. Shop windows were a way to sell TV sets as well as television broadcasts. But programmes in turn were also a way to promote television for retailers: in this instance, their shop windows were decorated with banners promoting the Tour de France.

This clip shows bystanders crowding together in front of the TV shops' windows while other occasional television viewers sit in a bar watching the Tour de France on television.

\subsection{An Appropriate System}

The longevity of this 'traditional' system owed a great deal to the gradual technical sophistication of television. In 1955, for example, one still had to 'destroy a tenacious legend: television works. ${ }^{22}$ On the contrary to the radio set, technical reliability was more important than the price for television. ${ }^{23}$ According to the Federation of Radio-TV manufacturers, this technical aspect justified the system of fixed prices ${ }^{24}$ After-sale services must be 'considered as one of the most

12 'Editorial sur les prix imposés,' Bulletin de la FNIE, 7, November 1959, 2.

13 F. Dupuy, J-C. Thoenig, La loi du marché, p.53.

14 Ibid., p.99.

15 'TV qui te construit?,' p.35

${ }^{16}$ Fédération Nationale des Industries Electriques et Electroniques, L'industrie électronique, p.89.

17 'Stations Services Philips,' for instance.

18 'TV où en es-tu?,' Electro -Magazine, 61, November -December 1956, p. 17

19 Fédération Nationale des Industries Electriques et Electroniques, L'industrie électronique, p.88

20 'TV, où en es-tu?,' p. 17.

21 'Une grande propagande “Télévision,” 'Electro-Magazine, 12, September-October 1951, 11.

22 Marcel Leclerc, Editorial, Télé magazine, 20th-26th November 1955.

${ }^{23}$ Interview with a former managing director of Thomson, 2004.

24 Editorial sur les prix imposés, Bulletin de la FNIE, 7, November 1959 
efficient factors to provoke increase in consumption. ${ }^{25}$ Therefore manufacturers had to fight against 'price spoilers. ${ }^{26}$ Closeness to consumers was one of the foundations of the system. Although manufacturers had reorganized a preexisting network, they had locked it on behalf of quality and technical specification, so they could sell their products at the prices they wanted. From then: 'approximately till the end of the sixties, those characteristics (expensive durable goods, but also new devices and technically advanced products) made it possible for traditional retailers to resist hypermarkets' competition [...]. The specialized network located in a district or in a town, proved good not only because it was easier to go and see the shop around the corner, but because as long as it was an expensive purchase, it was indisputable that the electrical and domestic appliances' specialized retailer was the more capable of giving information [...]. ${ }^{27}$ As long as television was a new, technically demanding and expensive product, it required the skills of a radio/TV specialist.

\section{Selling a Profitable Good: The Development of Other Kinds of Retailers on the Fringe of the Established System}

When TV sales boomed it caused an increase in new retail outlets and this was assisted by enabling legislation. However, television sales remained relatively limited until the beginning of the seventies, while manufacturers continued to bolster their 'traditional' networks.

\subsection{Legislation in Favour of Retailers}

Post-war legislative changes affecting the distribution of TVs clearly favoured retailers: whereas foreign television makers could strategically choose their retailers, French manufacturers could not. ${ }^{28}$ Despite minor adjustments in 1953, 1958 and in 1960, the Ministerial Circular from Joseph Fontanet, the Trade Minister, fixed prices as well as confirming refusals to deal during the period as far as French manufacturers were concerned. ${ }^{29}$ However, by the Act of 2 July 1963, French legislation introduced bans on below cost selling, but it was also unclear how a television maker was able to refuse to sell to a merchant offering introductory prices ${ }^{30}$ in order to attract customers in the hope that they would buy other more profitably priced items. The law continued to dictate a minimum level - the cost price - under which a retailer could not sell a product and sales below cost continued to be prohibited. The Decree of May 4th 1965 also attempted to regulate prices ${ }^{31}$ by setting maximum dealer profit margins. But manufacturers found themselves unable to control neither their brand portfolio nor their prices, despite protecting retailers; French legislation was primarily designed to protect consumers.

Ironically, this legislation had counter-productive effects for consumers. According to the Social and Economic Council in 1966, pricing was left 'up to the retailers,' competition was much more concerned with the amount of the rebates than with the prices of television sets. Manufacturers and importers 'had little by little increased the indicative prices of

\footnotetext{
${ }^{25}$ Fédération Nationale des Industries Electriques et Electroniques, L'industrie électronique, p.84.

26 Ibid.

27 Ibid.

28 lbid., p.54.

29 Centre d'étude des revenus et des coûts, Les circuits, p.107.

30 Ibid.

31 Situation de l'électronique en France, Journal Officiel de la République Française, Avis et rapport du Conseil économique et social, 26 -27 April 1966, p. 337. It determines the conditions under which indicative sales prices as well as basic prices of the manufacturers and the importers in the deals with the retailers must be fixed.
} 
their catalogues so as to reach the levels of their margins [...], so as to allow their retailers to grant large rebates. ${ }^{32}$ At the same time, French legislation made it possible for other kinds of dealers to develop.

\subsection{The Local and Limited Development of other Retailers}

In 1957, a contemporary retailer from Lyon indicated many more players in the market:

[T] he traditional radio retailers: they automatically sell TV sets. There are also former radio retailers who left this activity for selling household appliances. But there are also shopkeepers unfamiliar with the profession hoping, no doubt, that it will be highly profitable- yet they are poorly organised. There are others again, who are generally not so well located and who often grant discounts. Besides, some of them are affiliated to commercial bulk-buying organizations. At last, some storekeepers more or less out of the way [...] are doing door-to-door selling. ${ }^{33}$

The distribution system was an increasingly complex one now including the department stores ${ }^{34}$ and the 'educational direct marketing. ${ }^{35}$ This increasing number of retail outlets -18000 to 20000 at the end of the decade ${ }^{36}$ - was considered by some to ruin 'the reputation of the manufacturers. 37 The Discount Stores and the future speciality hypermarkets faced particularly criticism.

Indeed the larger, new discount stores had to be reckoned with more and more. ${ }^{38}$ They particularly relied on 'a low price policy'39 and they sold cheaper TV sets with no after-sale services. According to the manufacturers, they caused damage to the brands. ${ }^{40}$ Inaugurated in 1954, the Fédération Nationale d'Achat des Cadres (FNAC) was a different kind of agent, providing after-sale services, this joint buying organisation intended to provide 'good devices, honest advice and exceptional prices' thanks to a $20 \%$ discount. ${ }^{41}$ Darty emerged in 1957 ; prior to this, the Darty family ran a small clothing store in Montreuil. In order to extend their operation, they acquired a nearby store, where radio and TV sets were sold. Sold on the pavement cheap, the stock was turned over in a few days. ${ }^{42}$

Yet those kinds of retailers were mainly located in or around Paris until the seventies. ${ }^{43}$ In the rural regions, the distribution system was more basic. In Plozévet, in Bretagne, for instance, it was the local electrician who sold the television sets ${ }^{44}$ while the dealers of Philips and Thomson operated as kind of wholesalers within a given territory. ${ }^{45}$ Whether in Paris or in the provinces, the logic established in the fifties prevailed for some time: French manufacturers continued to control the larger part of the distribution system. It was more difficult and more expensive for foreign manufacturers to be in control of territories in which they were not directly established. Foreign intervention in the

32 Ibid.

33 'TV où en es-tu?,' p. 18.

34 'Tribune professionnelle,' Télé Magazine, 12th -18th February 1956, 35

${ }_{35}$ Centre d'étude des revenus et des coûts, Les circuits

${ }^{36}$ Fédération Nationale des Industries Electriques et Electroniques, L'industrie électronique, p.86.

37 'TV où en es-tu?,' p. 17.

38 'Tribune professionnelle,' Télé Magazine, 26 February-3 March 1956, p.35.

39 Commission des communautés européennes, Répercussions du Marché commun dans le secteur des biens de consommation électrotechniques, principaux résultats d'une étude empirique, Bruxelles, 1970, p.30. This increased competition is in particular attributed to the Common Market.

40 Rapport annuel de Schneider Radio -Télévision, 1965, Archives of the Crédit National, LT 1615.

${ }^{41}$ Contact, 16, 1957.

42 Darty's website.

43 J-L. Pétriat, Les années FNAC de 1954 à après-demain, Paris, Fayard, 1991, p.115. The FNAC is the symbol of consumerism. From 1964 until 1968, it went from 95 to 318 employees. In April 1964, there were about 200000 members.

${ }^{44}$ E. Morin, La métamorphose de Plozevet, Commune en France, Paris, Livre de poche, 1967, p. 96.

45 Centre d'étude des revenus et des coûts, Les circuits de distribution, p. 96. 
French market was made all the more difficult as the French technical broadcast standard of 819 lines, which was adopted practically only by France, reduced considerably the prospects of outside competition. At the same time, French manufacturers aggressively defended their territory.

\subsection{Manufacturers' Counter-Attack}

To protect and defend their nationwide brand networks, retailers focused on quality and service; when the 'prestige of French production' was in danger, they emphasised a quality label, indicated by a nameplate, a 'certificate of super Professional Guarantee and their retailer's networks. They intended to distribute 'quality materials at the lowest price with the maximum of services,' so as to make prices fall 'by a compromise between manufacturers and retailers. ${ }^{.46}$ At the same time, manufacturers began to extend and rationalize their own networks.

In 1964, according to the Schneider Radio/TV firm, 'the problems of distribution were to get organized so as to deliver the sooner they could and with the lowest cost. The result was the necessity of decentralizing distribution services and thus [...] to engage in a politics of creating regional depots and therefore they created regional depots in Nancy and Toulouse. ${ }^{47}$ By 1968, the company's network was much more extensive, organized around four key wholesalers 'having territorial exclusivity.' The network served large regions: the Nord-Pas-de-Calais, the Bourgogne, the FrancheComté, and the region of Bordeaux, the Ardèche. It was also by then organized into a direct network with seven regional centres. 'All the members of commercial staff were employees of the company' - staff who were faithful to the brand. ${ }^{48}$ The firm also relied on other kinds of distribution at the end of the sixties. They marketed their 'economic' receivers by parallel networks. ${ }^{49}$ Yet, according to them, even in those kinds of sub-networks, the service had to remain the cornerstone. ${ }^{50}$

By 1971, the 'traditional' retailers still held the position as national leaders with the majority market share for black and white TV sets. ${ }^{5152}$ This control of the marketplace was fundamental when 'the problem was no longer the lack of supply but the control of the demand, and the sales. ${ }^{.53}$ But at the beginning of the seventies the black and white TV set was not the costly and technically demanding object it had been during the last two decades. The colour TV set was arriving and the commonplace black and white television set was becoming less and less sold by the 'traditional' retailers.

\footnotetext{
46 'Situation et perspective dans la distribution radio télévision,' SCREM revue, 1, July 1963, p. 9-10.

${ }^{47}$ Rapport annuel de Schneider Radio -Télévision, 1964, Archives of the Crédit National.

48 Rapport du Crédit National sur Schneider Radio-Télévision, 1968, p. 9, Archives of the Crédit National.

49 Rapport annuel de Schneider Radio -Télévision, 1965, Archives of the Crédit National.

50 Ibid.

51 CETELEM, Votre dossier brun pour 1975, CETELEM'Archives, p. 21 According to the CETELEM, this could be explained by the ascendancy of a short cycle which saw the manufacturers dealing for the main part directly with retailers network without going through the channel of a wholesaler - and thus to exercise a more direct seizure by the distribution and by the requirements of the consumer in service after-sale. The psychological factor and, in particular, the customization of the relation between buyer and salesman, element of reassurance, also played an important role.

52 Commission of the European Communities, The European Consumer Electronics Industry, Bruxelles, 1985, p.150. The rural character more or less pronounced of a country could also explain this ascendancy.

53 F. Dupuy, J-C. Thoenig, La loi du marché, p.74.
} 


\section{Selling a Commonplace Object: How Hypermarkets displaced Traditional Retailers at the End of the Seventies}

Whereas black and white television sets were increasingly imported, they were also increasingly distributed through modern discounters such as the major food retailers. Manufacturers failed to prevent those retailers from taking advantage of the law. Whether this was ultimately in the best interest of consumers was a debateable issue.

\subsection{The Breakthrough of the Large Super Stores}

From dominating the television market at the beginning of the decade, by 1984, the traditional retailer was 'almost excluded'54 from the market. Although they were not television retailers in $1971,{ }^{55}$ the large-store specialist equipment departments of the house and food hypermarkets held more than half of the market of black and white TV sets by 1985 , and by then, they already had about $40 \%$ of the new colour TV market. ${ }^{56}$ The independent businesses - mainly the traditional retailers - saw their market share decrease from 84 \% to 53 \% between 1969 and 1981.

This loss of market share was not uniformly experienced in all areas. ${ }^{57}$ The number of Darty's outlets for instance had increased considerably. At the end of the sixties there were only three of their stores ${ }^{58}$ but by 1983 , there were 74 of their stores across France ${ }^{59}$. The number of large, supermarket stores had risen from 5 in 1966, to 492 at the beginning of $1983,{ }^{60}$ but there were still significant regional differences. At the beginning of the eighties: 'in the urbanized regions [...] traditional retailers saw their market share declining, apart from in the rural regions or in areas of low population density, which were less covered by major food retailers. ${ }^{61}$ The way retailing was organized was 'different, as it was a question of forwarding products to the urban zones [...] or the rural zones and the mid-sized cities, in the regions where the wholesalers were well established and were efficient or in the less structured areas; in the Paris region, in the regions where specialized hypermarkets ${ }^{62}[\ldots]$ were well settled or the regions where these retailers were not there. ${ }^{\prime 63}$ The contemporary data failed to show what the influence of this factor might have been. Manufacturers, perhaps understandably, singled out these new players, who according to them, were strongly disturbing the market.

\footnotetext{
54 Ibid.

55 CETELEM's Archives, CETELEM, Votre dossier brun pour 1975, p.12.

56 CERC, Les circuits de distribution, p.64. The part represented by the specialized hypermarkets is difficult to estimate. According to the CERC, the market share within the sector of electronic household appliances of three 'big integrated (joined) specialists (Darty, the FNAC, Boulanger)' reached $10,5 \%$ in 1981 . Their progress is the strongest in the electro acoustics with $12 \%$ of market shares in 1981 against $2 \%$ only in 1969 .

57 J -L. Pétriat, Les années FNAC, p.147 -155.

58 CERC, Les circuits de distribution, p.47.

59 Ibid.

60 Ibid., p.44.

61 Ibid., p.73.

62 Ile-de-France, the Nord -Pas -de Calais, the Normandy, the Alsace - Lorraine, Rhône-Alpes, Provence - Mediterranean Sea.

63 lbid., p.102.
} 


\subsection{Manufacturers' Fears of Large-Super Stores}

The Chief Executive Officer of the Radiotechnique put it clearly:

[T]he start-up stage [of these discount stores], was Sir $20 \%$ which had created a store next to the station Saint-Lazare [...]. Firms like these exhibited sets with less than the $20 \%$ discount, and less the $25 \%$ discount so that they tried hard not to sell them because they did not earn enough money on them. So, for instance, they showed a Philips television set with a rebate of $20 \%$. When you went to the store (and encountered the salesman):

"Hello Sir ... Well, are you sure that it's a Philips set you would like? It does not look terribly good. Look at this one..."

They tuned the other one well, but the Philips was not correctly tuned in ... They said: "have you seen that?" And you left without $20 \%$ discount and with a television set of another brand [...]. There is a saying: "I am not rich enough to buy myself cheap stuff." If it is what we gained, then to sell more television sets and to sell them at a loss that seems to me rather funny. ${ }^{64}$

His words show how difficult it was for the manufacturers to deal with discount stores at this stage.

This drift of the sales, which used the brands as loss leaders, was a strategy that the hypermarkets practised on a large scale. Those major food retailers like Auchan and Carrefour ${ }^{65}$ had learned a lot from Bernardo Trujillo and the National Cash Register. They knew that an 'island of losses in an ocean of profits' was worthwhile. In most cases you could buy your TV set on the spot to take away, but there were no after-sale services. It was a case of attracting a large customer base by some prestigious articles, and then diverting the buyers towards other products. ${ }^{66}$ But large super stores also tried hard little by little 'to couple with their price policy, a politics of service.' They attempted to imitate specialized hypermarkets. Darty provided an illustrative model. ${ }^{67}$ 'Super retailer,' Darty was running its servicedepartment, seven days a week. ${ }^{68}$ This service was expensive: it represented about $3 \%$ to $5 \%$ of its turnover, but it proved worth it. As regards the prices, 'obtaining favourable buying conditions was facilitated by the possibility and importance of the volume of their sales.' At the same time, there were aggressive advertising campaigns, designed to persuade consumers that 'Darty was the good one. ${ }^{69}$ But if these claims were made on behalf of the consumer, did they actually benefit the consumer and the development of the market?

\subsection{For the Benefit of the Consumer?}

The costs of distribution of television sets at this time are difficult to estimate. It is difficult to establish precise comparatives, although at the beginning of 1980s, a detailed estimation of the costs incurred by the retailers and the consumers is available. ${ }^{70}$ This indicates that with the new forms of retailing, one could purchase a television at a lower

\footnotetext{
${ }^{64}$ Interview with a former managing director of Thomson, 2004.

65 That finding, too, needs to be qualified as far as Carrefour is concerned: see Jean -Claude Daumas, 'Consommation de masse et grande distribution: une révolution permanente (1957 -2005),' Vingtième siècle, no. 91, July-September 2006, p. 57-76.

${ }_{66}^{6}$ F. Dupuy, J-C. Thoenig, La loi du marché, p.107.

67 Ibid., p.42.

68 Ibid., p.113.

69 Ibid.

70 CERC, Le coût de la distribution des appareils électrodomestiques, la Documentation Française, 1989.
} 
cost, for an equivalent after-sale service, and even for a superior after-sale service. ${ }^{71}$ The specialized department store - the definition of which was not clearly given, but large super stores like Darty or the FNAC were part of it had the most reasonably priced set (1104 francs). The hypermarket was also reasonably priced compared to the specialized department store and the traditional retailer, at 1138 francs, the price was only $3 \%$ more expensive than the specialized department store.

But cost price was not enough to evaluate this market, for televisions required maintenance. After-sales service stood for about $40 \%$ of the gross margin of a 61 centimetres (24 inch) black and white television set at the beginning of 1980s. Small retailers had at that stage, with the regional specialists, the highest gross rate of margin ${ }^{72}$ and even if they benefited from their terms of purchase, ${ }^{73}$ these did not compensate for the supplementary cost postsale expenditure. ${ }^{74}$ Paradoxically 'the differences of service did not explain the different levels of the sales prices. ${ }^{175}$ According to another study, 'both categories of retailers, who seemed to be in 1982 the most profitable for the consumer, [were] the big national specialists and the hypermarket. ${ }^{176}$ The small retailers were then less profitable for the consumers, even if they were closest to them and globally sold television sets comprising top-quality properties. ${ }^{77}$ This visible advantage on the prices could change in the long term into disadvantage for the consumer.

The outwardly more consumerist model of the specialized hypermarkets covered up practices, which were not consumer-oriented at all. The household appliances retail sector was highly concentrated ${ }^{78}$ with about 20 retailers controlling $40 \%$ of the 'brown' household appliances market in $1981 .{ }^{79}$ The big national specialists (la FNAC, Darty, etc.) boosted the large circulation of TV set models on which they had almost a monopoly and which were 'pre-sold.' Some vendors were under the regime of sales commission. ${ }^{80}$ As an embodiment of this retail system, Darty, with about $10 \%$ of the 'brown' household appliances market share and 80 outlets at the end of our period, showed 'a profitability among the best of the profession. ${ }^{\prime 21}$ In a specific geographical area and in its particular catchment area, Darty was looking for the brands, which sold the best among its prime competitors, lowering its prices if necessary and hence undermined the selling points chosen to attract the consumer by these competitors. ${ }^{22}$ Having obtained a significant proportion of market share (15-20\%), it then increased its television prices. Retailers like this also included the secondary services in the sale, in particular various additional guarantees, which were very lucrative for them. ${ }^{83}$

\section{Conclusions}

In France, as in many other countries and regions of Europe, retailers were fundamental to the 'take-off' and expansion of the black and white television set, from a technical to a 'commonplace' product and the small scale 'traditional' retailer gave way to the hypermarket by the end of the period under review. By then, retailers could no longer rely on good salesmen, or in particular, on good technical and maintenance services. They had to offer

\footnotetext{
71 That is how the CETELEM compared in 1972 the prices of standard and multi-standard black and white television sets. Price differences reached about $14 \%$. The unspecialized department store was the most expensive (1258 francs). The small specialized business offered a TV set that $2 \%$ cheaper.

$7232 \%$ for the small specialists against $30 \%$ on average for all the retailers and $20 \%$ for hypermarkets.

73 Ibid., p.138.

74 Ibid., p. 140

75 lbid., p.11.

76 Ibid., p.143.

77. CERC, Le coût, p. 148.

78 . CERC, Les circuits de distribution, p. 64

79. CERC, Le coût de la distribution, p. 8. They realize $36-37 \%$ of the total sales of the electro-acoustics. Three big specialized hypermarkets have the main share of the market: Darty, la FNAC and Boulanger. About ten hypermarkets and supermarkets realize the main part of the turnover of the food hypermarkets. And the competition is 'far from being keen.'

80 F. Dupuy, J-C. Thoenig, La loi du marché, p.112.

81 Ibid., p.110.

82 Ibid., p.115.

83 CERC, Le coût, p.52.
} 
attractively priced products and the major food retailers offered such attractive prices. They achieved the aims of Bernardo Trujillo: 'an island of losses in an ocean of benefits,' which proved ineffective at defending or protecting manufacturers brands. It took a long time for them to decide to provide after-sale services. However, with the advent of new TV products like colour television, retailers more and more followed the model of the specialized hypermarket. These combined competitive pricing strategies, and with their dominant sales capacity and volume, they could also choose the best television brands. They also began to provide comprehensive after-sale services, although purporting to act on behalf of the consumer; they were, however, acting for themselves and in their own commercial interests. They competed directly and aggressively with the 'traditional' retailers and by taking advantage of their market power they were able to become independent of manufacturers and to focus on price, which was ultimately good for the consumer as well as for TV sales.

To what degree is this French case the exception rather than the rule? To what extent did certain forms of sales and distribution like the large electronic specialised stores (FNAC, Darty) also exist in other European countries? Did the different European national markets and distribution channels for the TV also switch to more discount systems, as television became more and more an accepted and ordinary part of the post-war home? Was the French 'culture' of distributing goods and services by comparison more focused on large supermarkets or did a 'discount' culture exist elsewhere, for example in Germany, where Lidl was born? The evolution of French distribution systems for television also provides a significant way to shed light on key changes in the status of television in France in this formative period. Could the same trends be observed at pan-European levels? At this stage we lack comparative and complimentary European studies and perspectives, so these questions remain unanswered at the moment. However, this study of the French case, should serve to provoke and stimulate future research and exploration, which will provide a more complete picture of the history of TV retailing at the European level.

\section{Biography}

Isabelle Gaillard is a lecturer at the University Pierre-Mendès-France (Grenoble II). Her research and teaching expertise is on teaching: history of consumption and history of the media, especially television history. Her PhD thesis, published in 2012, was about television as a consumer commodity from the 1950s to the 1980s. 